\title{
The Effect of Two-Dimensional Factor on Municipal Civil Servants' Job Satisfaction and Public Policy Implications*
}

\author{
Nguyen Ngoc Duy Phuong ${ }^{1}$, Mai Ngoc Khuong ${ }^{2}$, Le Huu Phuc ${ }^{3}$, Le Nguyen Thanh Dong ${ }^{4}$
}

Received: May 27, 2018 Revised: July 12, 2018 Accepted: July 30, 2018

\begin{abstract}
The purpose of this study was to examine the effect of two-dimensional factor of motivators and hygiene on civil servants' job satisfaction using the partial least square structural equation modeling (PLS-SEM) as a technique employed to analyze the measurement and structural models. Exploratory study was deployed to evaluate the relationship among variables. By using multistage stratified sampling, statistical data was collected from a survey of 441 public municipal civil servants who have employed in various levels (municipal government, districts and communes) in Vietnam. The findings provided evidence that hygiene factors (relationship with leader, salary, relationship with coworker and working environment) directly impact on civil servants' job satisfaction. Meanwhile, only career development factor from motivators significantly influenced on public employee's job satisfaction. Based on the empirical results, the hygiene factors of job satisfaction are more dominated that the motivators one. This finding suggests that municipal governments should focus policies on improving the hygiene factors which lead to higher job satisfaction on civil servants. Gaining a thorough understanding of the determinants of job satisfaction toward municipal public servants will enable policy makers to grasp the factors that results in retaining employees. Finally, the policy makers can use this knowledge to promote civil servants' job satisfaction.
\end{abstract}

Keywords: Civil Servants, Hygiene, Job Satisfaction, Motivators, Vietnam.

JEL Classification Code: M48, M54, Z18.

* The paper was presented initially at 2018 International Conference on Business and Economics (ICBE2018) and the 14th International Conference of KODISA that was held in Seoul, South Korea, June 25-27, 2018. The paper has been recognized as one of Best Paper Awards at ICBE2018 conference. This paper is a substantially revised and expanded version of the paper presented at ICBE2018 conference. The authors have taken into account all the comments of Editors, Session Chairs and Reviewers in the revised manuscript. The authors greatly appreciate Editors, Session Chairs and Reviewers for their valuable comments, interest in and support of this research.

1 First Author and Corresponding Author. Professor, International University, Vietnam National University, Ho Chi Minh City, Vietnam [Postal Address: Quarter 6, Linh Trung Ward, Thu Duc District, Ho Chi Minh City, 700000, Vietnam]

Email: phuongnida@gmail.com

2 Professor, International University, Vietnam National University, Ho Chi Minh City, Vietnam Email: maingockhuong@yahoo.com

3 Graduate student, International University, VietnamNational University, Ho Chi Minh City, Vietnam

$4 \mathrm{PhD}$ student, International University, Vietnam National University, Ho Chi Minh City, Vietnam Email: donglnt@uef.edu.vn

\section{Introduction}

Job satisfaction is one of the most popular concepts in many fields, including organizational or sociological perspectives and psychological or career perspectives (Herzberg, 1966; Lock, 1969; Scarpello \& Campbell, 1983; Wright \& Davis, 2003). Many agree that there are links between the employees and the organization environment. Job satisfaction has been the subject of a large number of studies and also an important indicator of the effect of conditions in the workplace or worker attitudes. Olsen (1993) suggests job satisfaction as the positive emotional feeling resulting from attaining what one wants or values from a job. Therefore, job satisfaction is indeed of great importance in every single company or organization, especially those that involve the employment of a huge number of employees. The reason for this is because job satisfaction "is an indicator of how well a person is doing his or her job" (Tanjeen, 2013). Such performance of all employees determines the success of organizations. However, dissatisfied workers cause idleness, withdrawal, burnout, absenteeism and workplace aggression (Lawler, 1994; Spector 1997). 
Job satisfaction in public sector has also received much attention from scholars. Some argue that the main reasons people work in the public sector is because it provides sense of satisfaction (French et al., 2010). In different angle, some studies suggest that workers view their employment in the public sector merely as an opportunity to take advantage of its social benefits while spending their energy elsewhere or to gain professional experience for later private-sector employment (Perthes, 1995) or low morale may be led to low productivity (Durst \& DeSantis, 1997). Additionally, most empirical research of this area has been done in the developed countries where as there are huge differences of public employees in developing countries contexts, especially there is limited evidence about job satisfaction of civil servants in Vietnam.

In Vietnam nowadays, the number of people working for the government accounts for a large proportion. According to national statistics published in 2016, Vietnam has got 2,8 million civil servants in all areas in the whole country. The government has been attempting to improve its administrative reform to match with the global integration. Initially, the results have come positively to the public. However, it may bring the burden and stress to public servants as well as the whole system due to the high requirements to serve public better. Apart from that, Vietnam also adopts a unique party-state regime which is completely different in political, institutional and cultural elements. It is therefore a need to explore the key determinants on job satisfaction of municipal civil servants. The results are expected to support the generalizability of job satisfaction theories and produce practical policy implications for our country.

\section{Conceptual Framework and Hypotheses Development}

\subsection{Job Satisfaction}

Job satisfaction is indeed one of the biggest concerns for organizations and companies. There is no universal consensus on the meaning of job satisfaction. Its meaning has been defined in several ways. A very early study on this issue, Hoppock (1935) viewed job satisfaction as the combination of natural, psychological and physiological circumstances. Some researchers considered it as a positive emotion about one's job. Locke (1976) defined job satisfaction as the pleasure or positive emotional feelings of employees towards their own jobs. This means that if employees are satisfied with their jobs, they will highly be happy and be a positive person at work. This explanation is rather the same as the definition of Robbins and Judge (2009). These two authors had defined job satisfaction as "a positive feeling about a job resulting from an evaluation of its characteristics." Similarly, Job satisfaction as "a pleasurable or positive emotional state resulting from the appraisal of one's job or job experiences" is the definition given by Nelson and Quick (2009).

In another context, Comm and Mathaisel (2000) indicated in their study that "job satisfaction is influenced by the level of pay and performance, employee benefits, training, recruiting, learning curve inefficiencies, reduction in the client base, job design, life satisfaction, autonomy, growth satisfaction, satisfaction with co-workers, satisfaction with supervisors and customer satisfaction." Lee-Kelley et al. (2007) argued that job satisfaction can help companies and organizations evaluate "an employee's attitudes of overall acceptance, contentment, and enjoyment in their work." In addition, Heathfield (2011) proposed that employees' job satisfaction can determine whether an employee is happy, content at work or not and it can also help an employee fulfill their desires and needs at work. Moreover, Mohammed and Eleswed (2013) suggested that job satisfaction directly affects positive work attitude. "A satisfied employee is more likely to be creative, flexible, innovative and loyal."

The determinants of job satisfaction have been addressed by several scholars. Herzberg (1966) introduced the model of work motivation with two factors: intrinsic factors and extrinsic factors. Intrinsic factors are what bring job satisfaction, on the other hand, extrinsic factors bring dissatisfaction and reduce the level of job satisfaction. According to this author, the intrinsic factors are also called satisfiers and motivators, included creative or challenging work, responsibility and advancement opportunities. Deci, Connell, and Ryan (1989) said that intrinsic motivation, which is the motivation to perform an activity for it, can help employees experience the pleasure and satisfaction inherent in the activity. In more particular, Hirschfield (2000) explained that intrinsic job satisfaction was how employees feel about the jobs themselves, or the nature of the job. While extrinsic job satisfaction was how employees feel about the aspects outside of the work itself. Based on Gagné and Deci (2005), rewards that are interpreted as information about one's competence and satisfy individuals' need for autonomy, will enhance intrinsic motivation.

Kovach (1987) indicated the relationship between work motivation and job satisfaction of employees. According to him, being provided with enough basic necessities of life makes employees motivated, which in turn brings them satisfaction from their jobs. In the perspective of customers, Brown (1996) illustrated that when a company or an organization has got joyful and satisfied employees, there is 
high probability that they will have joyful and satisfied customers. The two-dimensional factor proposed by Herzberg (1966), suggest that intrinsic factors like rights and responsibilities, career development, job description and teamwork can make public employees a whole lot more satisfied at work while extrinsic factors like leadership, relationship with coworker, salary and working conditions can make the job less satisfied, in other words, can dissatisfy public employees if these factors do not live up to their expectation. The model with eight variables and research hypotheses is discussed below.

\subsection{Rights and Responsibility}

Every single employee has their own rights and responsibilities at the workplace. Baah and Amoako (2011) suggested that motivational factors such as, the responsibilities that are granted to employees will help employees feel worth with respect to the values they get from the companies or organizations. Moreover, this can increase their level of motivation. This level of motivation will increase their internal happiness. And the degree to which they are happy internally will bring about job satisfactions. Thus, rights and responsibilities have a direct influence over job satisfaction. Hence, we propose:

\section{$H 1$ : Rights and responsibilities positively affects civil servants' job satisfaction}

\subsection{Career Development}

Gilley and Eggland (1989) defined career development as an organized planned effort consisting of structured activities or processes that result in mutual career plotting effort between employees and the organization. Schein (1978) argued that to achieve both organizational effectiveness and individual satisfaction, there should be good matching of organizational and individual needs. This will help an organization to link and build a better career development programs that will meet the objectives of both the employees and the organizations. Chemeli (2013) said that employees have a tendency to have control over their careers, want greater job satisfaction and more career options. Nel et al. (2004) said that if employees are to be given the ability to advance in their organization, their quality of work life will be increased. He also concluded that if employees know they can advance in their organizations, they will experience less frustration and greater job satisfaction. Chemeli (2013) concluded that career development work in a win-win pattern. Both employees and the organizations will gain. The employees will have greater personal satisfaction and better personal development, while the organizations will obtain increased productivity and creativity. It can be assumed that:

H2: Career development positively affects civil servants' job satisfaction

\subsection{Job Description}

According to Barbouletos (2011) job description is a framework defining a position. Job descriptions can include specific tasks, responsibilities, specifications, broad goals, competencies, and knowledge desired by the company. Job description is one of the two components of job discrepancy. Based on the results of Barbouletos (2011), he concluded that job discrepancy has a positive effect on job satisfaction. According to his findings based on data, the higher the job discrepancy, the higher the job satisfaction. In more particular, the attractiveness of the job creates the job satisfaction for that job. This attractiveness is not only about an expected job, but also about the supervision employees receive at work, the support from leaders while at work, rewards, compensation, and so on. When the job description matches the employee's capability, strengths, he or she will be more willing to accept the job, hence increasing the likelihood of having more satisfaction from the job. When employees are satisfied, they will perform better, and have bigger productivity. Therefore, managers, leaders and supervisors had better arrange jobs based on the individual's characteristics so that employees can have suitable positions at the workplace. Based on those arguments, we suggest that:

\section{H3: Job description positively affects civil servants' job satisfaction}

\subsection{Teamwork}

Teamwork is defined as a "unit of two or more people who interact and coordinate their work to accomplish common goal" (Musriha, 2013). There is a saying that goes like "If you want to go fast, go alone. If you want to go far, go together". Nowadays, teamwork is an important part in every company and organization. Without teamwork, a company or organization can hardly achieve any goal. Robbins and Judge (2009) said that when people work in a team, it means that they are willing to use their positive energy, mutual accountability and complementary skills to work intensely on a specific, common goal. Thompson (2011) defined that a work team is an interdependent group of people who share accountability for common outcomes for 
their organizations. Daft (2013) said that to forming an effective team that can work together requires many factors such as clear goals, trust for each other, united commitment, good communication, internal and external support and so on. Bell (2007) proved that by enhancing these factors within a team, "team composition is believed to have a strong impact on team performance." When a united effective team work well together and have a good team performance, it is highly likely that people will become a lot more satisfied with their team, their job and their organization. Team work plays a vital role in enhancing employee performance and self-motivation (Griffin, Patterson, \& West, 2001). Saleem et al (2012) confirmed that the more connection between individuals is needed, the more influential teamwork is toward job satisfaction.

\section{H4: Teamwork positively affects civil servants' job satisfaction}

\subsection{Salary}

Many researchers around the world agree salary as a factor that has a considerable influence on job satisfaction. Because it is easy to understand that the higher an employee get paid for their job, the more attractive and satisfying the job is to them. On the contrary, with jobs that are low-paid, hardly does any employee enjoy doing that job. Kabir and Parvin (2011) found that salary can affect job satisfaction of a person. Teck-Hong et al. (2011) discovered that employees who receive a pay increase would be more satisfied with their job. Kabir et al. (2011) conducted a study and results showed that relations with coworkers, work efficiency, supervision and salary have a significantly large influence on the level of job satisfaction of employees. DíazSerrano et al. (2005) undertook an examination about low and high paid workers' job satisfaction in the European Union. Results from this examination showed that compared to high paid employees, low paid employees experienced a lower level of job satisfaction. Sweet et al. (2006) suggested that the payment has a strongly closed relationship and have a direct impact on job satisfaction.

\section{H5: Salary positively affects civil servants' job satisfaction}

\section{7, Leadership}

Leadership is a process in which a person has an influence over a group of people working together to achieve a common goal (Flynn, 2009). Naidu and van der Walt (2005) indicated that a leadership style is effective if it creates changes and the impetus for innovation. Jones and
Rudd (2007) called leadership as a relationship between leaders and those who follow such leaders within a group. Judge et al. (2001) proved that the key component of leadership is valuing employees' job satisfaction. Some studies have pointed out that the if an organization adopts the participative management style, together with pay attention to communication and rewards for employees, employees will be much more likely to be satisfied (Mckinnon et al., 2003). According to Belias and Koustelios (2014), many researchers have shown that there are two types of leadership style which are most influential to employees' job satisfaction, namely transactional leadership and transformational leadership. Transactional leaders are those who act based on the organizational culture. While transformational leaders tend to act towards change and transformation to fulfill their vision. Bushra et al. (2011), from an investigation of 133 bank employees in Pakistan about the relationship between transformational leadership style and job satisfaction, announced that this leadership style has a positive influence on the job satisfaction of employees.

H6: Leadership Style positively affects civil servants' job satisfaction

\subsection{Relationship with Coworkers}

Herzberg (1966) defined relationship with colleagues as "the social and working transactions with others on the job." $\mathrm{He}$ explained that whether a person feels satisfied or dissatisfied depends on whether that person perceives this relationship as being of a low or high quality because the relationship itself does not lead to job satisfaction. Ducharme and Martin (2000) concluded from their investigation on the problem relating to job satisfaction that work group interactions and coworkers' support have a positively significant impact on job satisfaction. Lin and Lin (2011) said that if a company wants to achieve at the same time high work performance and high job satisfaction, they have to build an environment in which there is good coordination between employees. Both Hackett and Guion (1985) and Bass (1990) came up with the same conclusion in their researches that relationships with coworkers have an effect on job satisfaction.

H7: Relationship with coworkers positively affects civil servants' job satisfaction

\subsection{Working Environment}

Working environment is the place where civil servants come and spend their working hour to work, including all the 
physical working conditions and companies' policies. Phuong and Tu (2017) suggested that the physical conditions of a working environment consist of many factors including buildings, office layout, equipment design noise, space, personal and property security. Arnold \& Feldman (1996) proposed some items in the working condition including temperature, lighting, ventilation, hygiene, noise, working hours, and resources because employees are more likely to prefer the conditions that can give them physical comfort and convenience. These conditions, according to Oldham (1988), can affect employees' attitudes and behaviors. Therefore, it is obvious that working condition has an influence over job satisfaction. To make employees more satisfied, companies and organization need to invest in creating and building a good working condition at the workplace. Therefore, we postulate:

H8: Working environment positively affects civil servants' job satisfaction.

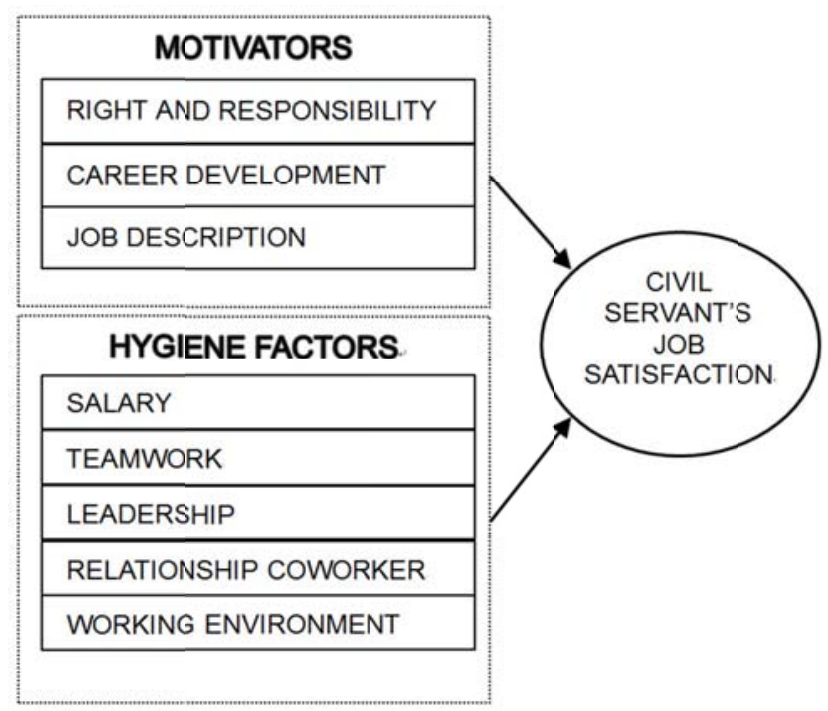

Figure 1. The proposed conceptual framework

\section{Research Methodology}

\subsection{Operationalization of Constructs}

This study used a survey instrument that consists of 2 sections: the first section identifies the demographic attributes of the respondent, and the second section measures the theoretical constructs of civil servants' job satisfaction. To ensure content validity, the survey items were derived from those used in previous studies. Each item was measured using a 5-point Likert scale. Rights and responsibility scale with six items were adopted from Baah and Amoako (2011). While career development scales including five items were adapted from Chemeli (2013) and job description with six items from Barbouletos (2011). A 5item scale was adopted from Saleem et al. (2012) to measure teamwork. Salary with five items was built from Kabir and Parvin (2011). A 7-item was constructed from Belias and Koustelios (2014) to measure leader. While relationship with coworker with six items was developed from Lin and Lin (2011) and working environment with a 7item from Arnold \& Feldman (1996). Finally, job satisfaction scale with four items was adapted from Mohammed and Eleswed (2013).

\subsection{Survey Administration, Data Collection and Statistical Method}

This study employed a quantitative method, using PLS_SEM statistical technic to test the conceptual model and developed hypotheses. The prospective respondents were chosen from public agencies of the Tay Ninh municipal governement, district-level governments and commune-level governments via a multistage stratified sampling. First, we divided all civil servants in Tay Ninh province into two strata: civil servants in the municipal government with 18 agencies, then was randomly selected five out of eighteen agencies. Second, civil servants in lower levels of governement (9 district-level and 95 commune-level) were randomly selected five of agencies. For the former one, we first obtained a roster of all civil servants and the simple random sampling was employed to select respondents in each agency. For the latter one, two district-level agencies and three communal offices were randomly selected.

The questionnaire was adapted through a thorough review of previous related literature and survey instruments. A pilot survey was also conducted to improve the reliability and validity of the construct. The respondents in this stage were civil servants from the public agencies. After modifying the questionnaire, the complete survey was conducted in November 2017. All 500 questionnares were sent to the selected respondents and 466 completed questionnaires were sent back, and the response rate was $93.2 \%$. Then we did the screening with questionnaires that have missing values. Twenty five of them were excluded, resulting in a final data set with 441 observation.

\subsection{Data Analysis}

To test the research model, this study used the partial least squares (PLS) technique of structural equation modeling using SmartPLS (version 3.0). This technique was 
selected because of its capacity to analyze a complicated model (Hair et al., 2011). As recommended by Hair et al (2013), this study applied the two-step approach for data analysis. The first step analyzed the measurement model, and the second step assessed the structural relationships among the latent construct. This approach was used to determine the reliability and validity of the measures before testing the structural relationship of the model.

\section{Empirical Results}

Among these respondents, $56 \%$ were males and $44 \%$ were females. In marital status, the number of single civil servants is only 131 respondents $(30 \%)$ and majority respondents married (70\%). Age was divided into 4 age groups. the largest proportion is from 25-35 years old, at $43 \%$. The second largest group is from $35-45$ years old, at $35 \%$. Next is the group of people over 45 years old. And the minority group belongs to those who are under 25 years old, at only $4 \%$. This implies that the job is more attractive to middle-aged people. In terms of tenure, It is clear from the chart that the group that accounts for the biggest percentage is those who have had from 5-10 years of experience, at $38 \%$. Ranking second is those of $10-15$ years of experience, accounting for 32 percent. The difference between the two group is not much.

From these two figures, it can be withdrawn that those who have chosen to pursue their careers as civil servants stays pretty loyal to the job. The group of $10-15$ years of experience has smaller number of people may be because of retirement. About education background, undergraduate civil servants make up the largest proportion, at $79 \%$. This means that the majority of people who are working as civil servants own a university degree. Vocational college accounts for $11 \%$, Post-graduate accounts for $6 \%$ and Junior college accounts for $4 \%$. It is noticeable that Postgraduate accounts for just 6 percent. This implies that jobs as civil servants are not attractive enough to people who have pursued high education. Finally, about income, group that accounts for the largest percentage is group of people who earn under 4 million VND a month, at $43 \%$. From this, it can be concluded that the salary of people working as civil servants is not high or attractive at all. Only $1 \%$ percent of respondents in this survey have an income of over 10 million VND.

\subsection{Measurement Model Analysis}

To test the reliability and validity of the reflective constructs, composite reliability (CR) was measured in relation to internal reliability. Table 1 shows that all constructs had $C R$ values above 0.7 , which satisfies the suggestion of Hair et al (2013) to accept items with loadings of at least 0.7 . Individual item reliability was deemed acceptable because all the loadings associated with each of the scales were greater than 0.7. Overall, 15-item was eliminated from the scale. The measurement scale remains thirty-six items for nine constructs.

Then, convergent validity was then assessed using the average variance (AVE), which was above 0.5 , thus indicating satisfactory convergent validity. In addition to the composite reliability $(\mathrm{CR})$, the average variance extracted (AVE) of these constructs achieved the cut-off point, indicating a satisfactory degree of reliability with ranging from 0.572 to 0.806 . This result indicates that the measurement model has demonstrated an adequate convergent validity (Chin, 1998), see Table 1.

Table 1. Measurement model evaluation of first-order factors

\begin{tabular}{|l|c|c|c|c|}
\hline \multicolumn{1}{|c|}{ Constructs } & $\begin{array}{c}\text { No. } \\
\text { Items }\end{array}$ & $\begin{array}{c}\text { Factor } \\
\text { loadings }\end{array}$ & AVE & CR \\
\hline Working environment (WE) & 6 & $0.734-0.792$ & 0.576 & 0.890 \\
\hline Job description (JD) & 4 & $0.855-0.921$ & 0.806 & 0.943 \\
\hline Right and responsibility (RR) & 4 & $0.785-0.907$ & 0.748 & 0.922 \\
\hline Relationship with leader (RL) & 3 & $0.787-0.843$ & 0.657 & 0.884 \\
\hline Relationship with coworker (RC) & 4 & $0.768-0.840$ & 0.633 & 0.838 \\
\hline Salary (SA) & 4 & $0.703-0.832$ & 0.572 & 0.842 \\
\hline Teamwork (TW) & 3 & $0.716-0.876$ & 0.648 & 0.846 \\
\hline $\begin{array}{l}\text { Career development (CD) } \\
\text { Job satisfaction (JS) }\end{array}$ & 3 & $0.791-0.907$ & 0.732 & 0.891 \\
\hline
\end{tabular}

Note: $\mathrm{CR}=$ Composite Reliability, AVE = Average Variance Extracted.

The discriminant validity was tested using the Heterotraitmonotrait ratio. All the ratios showed good discriminant validity properties (Table 2). On the basis of the Fornell and Larcker criterion, the square root of AVE for each construct exceeded the inter-correlations of the construct with the other constructs in the model (Table 2). Both analyses confirmed the discriminated validity of all the constructs. Table 2 shows that no indicator loads were higher in an opposing construct (Hair et al., 2013). The result of the measurement model indicates that various validity and reliability criteria were satisfied. Therefore, the constructs the constructs and their measures could be adequately discriminated and appropriated to predict relevance for the structural model and associated hypotheses. 
Table 2. Inter-correlations of the construct with the other constructs in the model

\begin{tabular}{|c|c|c|c|c|c|c|c|c|c|c|c|}
\hline & Mean & SD & CD & JD & RC & RL & RR & SA & TW & WC & JS \\
\hline CD & 3.774 & 1.219 & 0.855 & & & & & & & & \\
\hline JD & 3.872 & 1.466 & 0.420 & 0.898 & & & & & & & \\
\hline RC & 3.841 & 1.412 & 0.301 & 0.371 & 0.795 & & & & & & \\
\hline RL & 3.852 & 1.351 & 0.487 & 0.441 & 0.496 & 0.811 & & & & & \\
\hline RR & 4.132 & 1.283 & 0.179 & 0.245 & 0.131 & 0.034 & 0.865 & & & & \\
\hline SA & 3.572 & 1.267 & 0.387 & 0.278 & 0.321 & 0.322 & 0.114 & 0.756 & & & \\
\hline TW & 3.704 & 1.271 & 0.331 & 0.323 & 0.373 & 0.395 & 0.208 & 0.408 & 0.805 & & \\
\hline WE & 4.066 & 1.318 & 0.342 & 0.314 & 0.356 & 0.293 & 0.286 & 0.250 & 0.217 & 0.759 & \\
\hline JS & 3.794 & 1.254 & 0.487 & 0.312 & 0.505 & 0.549 & 0.041 & 0.440 & 0.352 & 0.354 & 0.813 \\
\hline
\end{tabular}

\subsection{Assessment of Structural Model}

In PLS, the predictive accuracy of the model was evaluated in terms of the portion of the variance explained. The results of such evaluation suggest that the model is capable of explaining $88.1 \%$ of the variance in job satisfaction. Apart from estimating the magnitude of $\mathrm{R}^{2}$ value, recent research has evaluated $Q^{2}$ value (the predictive relevance) suggested by Stone (1974) and Geisser (1975), as an additional model fit assessment technique. This technique indicates the ability of the model to predict the indicators of each latent variable. In regarding to the construct model, values of $Q^{2}$ with larger than zero with respect to a particular reflective endogenous latent construct indicate that the model has a relevant prediction power for that specific variable (Chin, 2010). Blindfolding procedure in Smart PLS was employed, the values of $Q^{2}$ are gained on a 7 omission distance. The present study obtained a calue of 0.299 for average cross-validated redundancy for all given endogenous variables. It is therefore the model exhibited an acceptable fit and high predictive relevance.

Additionally, nonparametric bootstrapping was applied (Wetzels et al., 2009) with 5000 replications to test the structural model. The significance of the direct effects specified by the research model were evaluated (Table 3 ). The results indicate that the effects job satisfaction is influenced directly by Relationship with leader $(\beta=0.250$, $t=4.128, \quad p<0.000)$, Salary $(\beta=0.237, t=4.099, p<0.000)$, followed by Career development $(\beta=0.203, t=3.909, \quad p<$ $0.000)$, Relationship with coworker $(\beta=0.185, t=3.696, p<$ $0.000)$ and Working environment $(\beta=0.113, t=2.287$, $\mathrm{p}<0.022$ ). As a result, hypotheses $\mathrm{H} 2, \mathrm{H} 5, \mathrm{H} 6, \mathrm{H} 7$ and $\mathrm{H} 8$ are supported, $\mathrm{H} 1, \mathrm{H} 3$ and $\mathrm{H} 4$ are not supported from the current study.
Table 3. Path Coefficient and Hypothesis Testing

\begin{tabular}{|c|c|c|c|}
\hline Hypothesis & Relationship & Path Coefficient & Decision \\
\hline H1 & CD -> JS & $0.203^{\star * *}$ & Supported \\
\hline H2 & JD -> JS & -0.050 & Not supported \\
\hline H3 & RC -> JS & $0.185^{\star * *}$ & Supported \\
\hline H4 & RL -> JS & $0.250^{* * *}$ & Supported \\
\hline H5 & RR -> JS & -0.083 & Not supported \\
\hline H6 & SA -> JS & $0.237^{* * *}$ & Supported \\
\hline H7 & TW -> JS & 0.028 & Not supported \\
\hline H8 & WC -> JS & $0.113^{* *}$ & Supported \\
\hline
\end{tabular}

t-values were computed through the bootstrapping procedure with 441 cases and 5,000 samples ${ }^{* *} p<0.05,{ }^{* * *} p<0.001$ (one tail)

\section{Discussion}

The aim of the study was to examine key determinants on municipal civil servant's job satisfaction using motivators and hygiene two-dimensional factors. The research results show that relationship with leader is the most important to predict job satisfaction. This completely agreed with the findings of Thoresen et al. (2001), and Mckinnon et al. (2003). It indicates that once employees feel connected to their leaders they will have strong satisfaction in the job, better job performance and much more positive work attitudes. In short, it is important that governmental agencies pay attention to their leadership so that they can increaser their civil servants' job satisfaction. This benefits both the civil servants and the organization.

Additionally, in line with the privies studies by DíazSerrano et al. (2005), Sweet et al. (2006), Kabir et al. (2011) and Teck-Hong et al. (2011), the results reveal the important effect of salary on job satisfaction of civil servants. Salary is a must to mention. Because it is undeniable that employees spend time and their intellect to work in exchange of money. Needless to say, money is somehow biggest motivator. However, despite the fact that salary is a big factor influencing civil servants' job satisfaction, it is not what happening in reality. Data has shown that at the moment, in Vietnam, salary paid to young governmental officials is too low for them to make ends meet. Some parents of these young people have to keep giving them financial support to so that they have money to cover living expenses. Thus, it is urgent for the government to make policies to improve salary for civil servants. This will be a big motivator for them. Once there is pay increase, a lot more things will be increased such as, job satisfaction, job performance, work productivity and so on.

The results also confirm the impacts of the career development on municipal civil servants' job satisfaction. This finding is consistent with that of Gilley and Eggland (1989), Nel et al. (2004) and Chemeli (2013). Excellent 
career development meet both business and employee needs. In today' workplace, career development is no longer the responsibility of the organization but it is the partnership between both sides. As a matter of fact, career development should be viewed from two perspectives: that of the organization and that of the employee. From the organization perspective, what needs to be asked is what skills and knowledge it should acquire to achieve its goal. On the other hand, from the employee perspective, the question is what skill and knowledge is needed for their future career plan. Specialists have pointed out that from organization perspective, they ought to develop career paths which allow employees to be fully aware of their options and opportunities that they can get to grown in their organization. Moreover, they should come up with strategies that pave way for gathering information to make sure what skills and knowledge they should acquire to achieve their goal. From the perspective of employees, they should make their own career plan based on their personal short term and long term goals and then discuss with their leaders. The leaders then will consult them based on the company or organization's strategies. Thanks to this, both the organization and the employees will benefit and have a good partnership in terms of career development.

Civil servants' job satisfaction is also determined collectively by relationship with coworker and working environment. These results are consistent with those of other previous studies as Ducharme and Martin (2000), Lin and Lin (2011) and Oldham (1988), Arnold and Feldman (1996), respectively. These results imply that civil servants work not only with leaders but most of the time, they spend time with coworkers. Thus, it is certain that to gain job satisfaction at the work play, good relationship with coworkers play a significantly important role. Hence, it is vital for civil servants to build up good and quality relationship with people working with them during the time they work there. If these relationships become good, they will serve civil servants well not only in terms of working, but also in their private life after work.

To build good relationship with coworkers, civil servants should pay attention to the following things. First of all, especially to those who work for the government, they need to always be courteous. Courtesy is one of the most important personalities if one wants to build good relationship with other people. The reason for this is that if one is courteous, they are highly attracted to other people. In addition, being polite makes one reliable. People will connect with and make friend to someone they find reliable. Reliability brings people the feeling safety. Secondly, build good communication with other people at work. It is not advisable at all to come to work and then go home without interacting with other people. One way to communicate is to make friend with coworkers who have things in common with you. Last but not least, provide the place of work where civil servants come and spend their time, including all the physical working conditions and companies' policies. Good working condition is contributing factor to employees' job satisfaction. Although several factors have significant effects on civil servants' job satisfaction, those from motivators as job description, rights and responsibilities together with teamwork showed no such direct effect. Those findings need further investigation to explore its nature.

\section{Implications and Conclusion}

This study provided several academic implications. First, based on the empirical results, the hygiene factors of job satisfaction are more dominated that the motivators one. This finding suggests that municipal governments should focus policies on improving the hygiene factors which lead to higher job satisfaction on civil servants. Therefore, future research may explore this two-dimensional factor on job satisfaction. In addition to its theoretical implications, this study offers recommendations for policy makers and managers in public sector. Gaining a thorough understanding of the determinants of job satisfaction towward municipal public serants will enable policy makers to grasp the factors that results in retaining employees. With such understanding, policy makers can improve their policies and strategies to ensure the successful human resources attraction policies in public sector. Finally, the policy makers can use this knowledge to promote civil servants' job satisfaction.

Before generalizing the discussed results, the limitations of the study should be taken into account. The present study centres on job satisfaction as dependent variable. Consequently, more research is needed to emmploy a longitude design and follow the behaviour of civil servants in public sector. Further more previous studies which used motivators and hygience factors, the linear relationship amongst the variables were investigated. The potential nonlinear relationships amongst variables can be investigated in future studies. Moreover, the current study was conducted in a border municipal in Vietnam which limits the findings generalisability strength to other provinces and cities.

\section{References}

Arnold, H. J., \& Feldman, D. C. (1996). Organisational Behaviour. New York: McGraw Hill.

Baah, K., \& Amoako, G. K. (2011). Application of Frederick Herzberg's Two-Factor Theory in Assessing and 
Understanding Employee Motivation at Work: A Ghanaian Perspective. European Journal of Business and Management, 3(9), 1- 8.

Bass, B. M. (1990). From transactional to transformational leadership: Learning to share the vision. Organizational Dynamics, 18(3), 19-31.

Barbouletos, S. (2011). Discrepancy between Role Expectations and Job. Descriptions: The Impact on Stress and Job Satisfaction. Master of Arts in Policy Studies, University of Washington.

Belias, D., \& Koustelios, A. (2014) Leadership and Job Satisfaction: A Review. European Scientific Journal, 10(8), 24-46

Bell, S. T. (2007). Deep-level composition variables as predictors of team performance: A meta-analysis. Journal of Applied Psychology, 92(3), 595-615

Brown, M. G. (1996). Keeping score: using the right metrics to drive world-class performance. New York, NY: Quality Resources.

Bushra, F., Usman, A., \& Naveed, A. (2011). Effect of Transformational Leadership on Employees' Job Satisfaction and Organizational Commitment in Banking Sector of Lahore (Pakistan). International Journal of Business and Social Science, 2(18), 261267.

Chemeli, S. P. (2013). The Influence of Gender and School Type on Secondary School Students' Personality Types and Career Aspirations in Eldoret West District, Kenya. Journal of Emerging Trends in Educational Research and Policy Studies, 4(2), 350-358.

Chin, W. W. (1998) The Partial Least Squares Approach to Structural Equation Modeling. Modern Methods for Business Research, 2, 295-336

Chin, W. W. (2010). How to Write Up and Report PLS Analyses, In Handbook of Partial Least Squares, 665-690.

Comm C. L., \& Mathaisel, D. F. X. (2000). Assessing employee satisfaction in service firms: An Example in Higher Education. Journal of Business and Economic Studies, 6(1), 43-53.

Daft, R. L. (2013). Organization Theory and Design. Boston: Cengage Learning.

Deci, E. L., Connell, J. P., \& Ryan, R. M. (1989). Selfdetermination in a work organization. Journal of Applied Psychology, 74(4), 580-590.

Díaz-Serrano, L., \& Vieira, J. A. (2005). Low Pay, Higher Pay and Job Satisfaction within the European Union: Empirical Evidence from Fourteen Countries. IZA Discussion Paper No. 1558. Available at SSRN: https://ssrn.com/abstract $=702889$

Ducharme, L., \& Martin, J. K. (2000). Unrewarding work, coworker support, and job satisfaction: A test of the buffering hypothesis. Work \& Occupations, 27(2), 223-243.

Durst, S. L., \& DeSantis, V. S. (1997). The determinants of job satisfaction among federal, state, and local government employees. State and Local Government Review, 29, 7-16.

Ellickson, M. C., \& Logsdon, K. (2001). Determinants of job satisfaction of municipal government employees. State and Local Government Review, 33, 173-184.

Flynn, S. I. (2009). Transformational and Transactional Leadership. Research Starters Sociology, 1(1) 1-6.

Fornell, C., \& Larcker, D. F. (1981). Evaluating structural equation models with unobservable variables and measurement error. Journal of Marketing Research, 18(1), 39-50.

French, J., Blair-Stevens, C., McVey, D., \& Merritt, R. (2010) Social Marketing and Public Health Theory and Practice. New York: Oxford University Press.

Gagné, M., \& Deci, E. L. (2005). Self-Determination Theory and Work Motivation. Journal of Organizational Behavior, 26, 331-362.

Geisser, S. (1975). The predictive sample reuse method with applications. Journal of the American Statistical Association, 70(350), 320-328.

Gilley, J., \& Eggland, S. A. (1989). Principles of human resource development. Cambridge, MA: Perseus.

Griffin, M. A., Patterson, M. G., \& West, M. A. (2001). Job satisfaction and teamwork: the role of supervisor support. Journal of Organizational Behavior, 22(5), 537-550.

Hackett, R. D., \& Guion, R. M. (1985). A reevaluation of the absenteeism -job satisfaction relationship. Organizational Behavior and Human Decision Processes, 35(3), 340-381.

Hair, J. F., Ringle, C. M., Sarsedt, M. (2011). PLS-SEM: Indeed a Silver Bullet. Journal of Marketing Theory and Practice, 19(2), 139-151.

Hair, J. F., Hult, G. T. M., Ringle, C. M., \& Sarstedt, M. (2013). A Primer on Partial Least Squares Structural Equation Modeling (PLS-SEM). Thousand Oaks, CA: Sage.

Heathfield, S. M. (2011). Human Resources Information System (HRIS)-HRIS Definition. Technical Report. Available at $\mathrm{http}: / /$ www.about.com

Herzberg, F. (1966). Work and the nature of man. Oxford, UK: World Publishing.

Hirschfield, R. R. (2000). Does revising the intrinsic and extrinsic subscales of the Minnesota Satisfaction Questionnaire short form make a difference? Educational and Psychological Measurement, 60, 255-270.

Hoppock, R. (1935). Job Satisfaction. New York: Harper.

Kovach, K. A. (1987). What motivates employees? Workers and supervisors give different answers. Business Horizons, 30(5), 58-65.

Jones, D. W., \& Rudd, R. D. (2007) Transactional, Transformational, or Laissez-Faire Leadership: An Assessment of College of Agriculture Academic Program Leaders' (Deans) Leadership Styles. Proceedings of the 2007. AAAE Research Conference, 34, 520-530.

Judge, T. A., Thoresen, C. J., Bono, J. E., \& Patton, G. K. (2001). The job satisfaction- job performance relationship: A qualitative and quantitative review. Psychological Bulletin, 127, 376-407.

Lawler, E. E. (1994). Motivation in work organizations. New 
York: Jossey-Bass.

Lee-Kelley, L., Blackman, D. A., \& Hurst, J. P. (2007). An exploration of the relationship between learning organizations and the retention of knowledge workers. The Learning Organization, 14(3), 204-221.

Lin, S. C., \& Lin, J. S. J. (2011). Impacts of coworkers' relationships on organizational Commitment and intervening effects of job satisfaction. African Journal of Business Management, 5(8), 3396-3409.

Locke, E. A. (1969). What is job satisfaction. Organizational Behavior and Human Performance, 4, 309-336.

Locke, E. A. (1976). The Nature and Causes of Job Satisfaction. In Dunnette, M.D. (Ed.), Handbook of Industrial and Organizational Psychology(pp.12971349), New York: McGraw Hill.

McKinnon, J. L., Harrison, G. L., Chow, C. W., \& Wu, A. (2003). Organizational culture: Association with commitment, job satisfaction, propensity to remain, and information sharing in Taiwan. International Journal of Business Studies, 11(1), 25-44.

Mohammed, F., \& Eleswed, M. (2013). Job Satisfaction and Organizational; Commitment: A Correlational Study in Bahrain. International Journal of Business, Humanities and Technology, 3(5), 43-53.

Musriha (2013). Influence of teamwork, environment on job satisfaction and job performance of the Cigarette Rollers at Clove Cigarette factories in East Java, Indonesia. Developing Country Studies, 3(2), 32-40.

Naidu, J., \& van der Walt, M. S. (2005). An exploration of the relationship between leadership styles and the implementation of transformation interventions. $S A$ Journal of Human Resource Management, 3(2), 1-10.

Nel, P. S., van Dyk, P. S., Haasbroek, H. D., Schultz, H. B., Sono, T., \& Werner, A. (2004). Human resources management (6th ed.). Cape Town: Oxford University Press.

Nelson, D. L., \& Quick, J. C. (2009). Organizational Behavior "ORGB". Mason, OH: South-Western Cengage Learning.

Oldham, G. R. (1988). Effects of changes in workspace partitions and spatial density on employee reactions: A quasi-experiment. Journal of Applied Psychology, 73(2), 253-258.

Olsen, D. (1993). Work satisfaction and stress in the first and third year of academic appointment. Journal of Higher Education, 64, 453-471.

Parvin, M. M., \& Kabir, M. M (2011). Factors affecting employee job satisfaction of pharmaceutical sector. Australian Journal of Business and Management Research, 1(9), 113-123.
Perthes, V. (1995). The Political Economy of Syria under Asad. New York: Martin's Press.

Phuong, N. N. D., \& Tu, H. N. (2017). Factors influencing employees motivation in VNPT Binh Duong. Vietnam Trade and Industry Review, 13(12), 90-95.

Robbins, S. P., \& Judge, T. A. (2009). Organizational behavior. (13ed.), Pearson Education.

Saleem, M., Anderson, C. A., \& Gentile, D. A. (2012). Effects of prosocial, neutral, and violent video games on college students' affect. Aggressive Behavior, 38, 263-271.

Scarpello, V., \& Campbell, J. (1983). Job satisfaction: Are all the parts there? Personnel Psychology, 36, 577-600.

Schein, E. H. (1978). Career dynamics: Matching individual and organizational needs. Boston, MA: AddisonWesley.

Spector, P. E. (1997). Job satisfaction: Application, assessment, cause and consequences. Thousand Oaks, CA: Sage.

Stone, M. (1974) Cross-validatory choice and assessment of statistical predictions. Journal of Research Statistics Society, 36(2), 111-133.

Sweet, J., Nelson, N., \& Moberg, P. (2006). The TCN/AACN 2005 salary survey: professional practices, beliefs, and incomes of US neuropsychologists. The Clinical Neuropsychologist, 20(3), 325-364.

Teck-Hong, T., \& Waheed, A. (2011). Herzberg MotivationHygiene Theory and Job Satisfaction in the Malaysian Retail Sector: The Mediating Effect of Love of Money. Asian Academy of Management Journal, 16(1), 73-94.

Tanjeen, E. (2013). A study on factors affecting job satisfaction of Telecommunication industries in Bangladesh. IOSR Journal of Business and Management, 80-86.

Thompson, P. (2011). The trouble with HRM. Human Resource Management Journal, 21(4), 355-367.

Thoresen, C. J., Bradley-Geist, J. C., Bliese, P. D., \& Thoresen, J. D. (2001). The big five personality traits and individual job performance growth trajectories in maintenance and transitional job stages. Journal of Applied Psychological, 89(5), 835-53.

Wetzels, M., Schroder, G. O., \& Oppen, V. C. (2009). Using PLS path modeling for assessing hierarchical construct models: Guidelines and empirical illustration. MIS Quarterly, 33(1), 177-195.

Wright, B. E., \& Davis, B. S. (2003). Job satisfaction in the public sector: The role of the work environment. American Review of Public Administration, 33, 70-90. 